\title{
The need to develop objective criteria for suitability as a surrogate mother: Reflections on Ex Parte KAF
}

\author{
D W Thaldar, BLC, LLB, MPPS, PGDip (Strategy \& Innovation), PhD \\ School of Law, Howard College, University of KwaZulu-Natal, Durban, South Africa, and associate member, KwaZulu-Natal Bar, South Africa
}

\section{Corresponding author: DW Thaldar(ThaldarD@ukzn.ac.za)}

This article points out a problematic lacuna in our law on surrogate motherhood, namely the lack of objective criteria for evaluating the suitability of a surrogate mother. The recent case of Ex Parte KAF - a case in which a surrogate motherhood agreement confirmation application was dismissed by the Johannesburg High Court - demonstrated how this lacuna can cause conceptual disjunction between the court and the clinical psychologist who evaluates the candidate surrogate mother. The solution suggested in this article is that clinical psychologists who evaluate candidate surrogate mothers should give urgent and careful thought to identifying such objective criteria, and start explicitly articulating these criteria in the reports that they file in surrogate motherhood agreement confirmation applications. This practice will give the court the opportunity to engage with such criteria and to develop precedents in this regard.

S Afr J Bioethics Law 2018;11(1):35-37. DOI:10.7196/SAJBL.2018.v11i1.618

The basic legal framework for surrogate motherhood is established in Chapter 19 of the Children's Act No. 38 of 2005..$^{[1]}$ In Ex Parte WH, ${ }^{[2]}$ the Pretoria High Court placed some essential flesh on the bones of the Children's Act. Subsequently, some other cases have also contributed to the law on surrogate motherhood. ${ }^{[3,4]}$ The most recent addition is Ex Parte $K A F_{,}^{[5]}$ which was decided on 10 August 2017 by the Johannesburg High Court. The purpose of this article is to analyse the contribution made by Ex Parte KAF to the development of our law on surrogate motherhood.

The growing body of case law on surrogate motherhood might cause one to ask whether it is fair to require commissioning parents and the surrogate mother to jump through so many legal hoops especially considering there are no similar legal requirements for procreating through sexual intercourse. The case law on surrogate motherhood is, in theory at least, merely clarification and elaboration of the law within the framework created by statute. It is the Children's Act in section 295 that inter alia requires: the commissioning parent(s) to be unable to give birth to a child and that the condition must be permanent and irreversible; the commissioning parent(s) to be suitable persons to accept parenthood of the child; and the surrogate mother to be a suitable person in all respects to act as a surrogate mother. ${ }^{[1]}$ The court gradually, on a case-by-case basis as required by the facts of a particular matter, applies the general principles of our law to the requirements stipulated by the Act. Metaphorically, the Act created the legal hoops, and the court determines how one is to jump through them - or, in the case of Ex Parte KAF, how not to jump through them.

I first discuss the facts and decision in Ex Parte KAF, and then analyse the potential impact of the judgment on the way in which clinical psychologists should prepare their reports on the suitability of the surrogate mother.

\section{Ex Parte KAF}

At face value, Ex Parte KAF is a typical surrogacy confirmation application: the applicants were the commissioning mother and father (a married couple) and the surrogate mother and her life partner. The commissioning couple had been married since 2006, but were not able to have a child. The reason for this inability, according to the reproductive medicine specialist who provided an opinion in support of the surrogacy confirmation application, was that the commissioning mother had a uterine septum which had been removed twice - but each time it grew back. The commissioning mother underwent five IVF cycles without success. Subsequent to these failures, the reproductive medicine specialist advised the commissioning couple that surrogacy was the only option if they wanted a genetically related child. Through the surrogacy programme operated by the reproductive medicine specialist's clinic, the commissioning couple were introduced to the surrogate mother, a 20-year-old, stay-at-home mother of two young children. The surrogate mother's life partner is in full-time employment. All the applicants were interviewed by a clinical psychologist, who provided positive reports on the suitability of both the commissioning couple and the surrogate mother. At least superficially, the application appeared to be problem-free and set for success in court.

Despite the apparently standard nature of the surrogacy application, it was dismissed for three reasons, each being sufficient: (i) concern about surrogacy as a means of income; (ii) concern about the intended surrogate mother's psychological wellbeing; and (iii) concern about the impartiality of healthcare professionals.

The first reason was that the intended surrogate mother was likely to use surrogacy as a means of income. According to the proposed surrogate motherhood agreement, the commissioning parents would reimburse the intended surrogate mother for pregnancy-related expenses up to ZAR4 000 per month - increasing to up to ZAR6 000 per month after she falls pregnant. Although the proposed surrogate motherhood agreement provided examples of pregnancy-related expenses, these examples were not exhaustive and there was no budgetary limit on any specific item. (Ex Parte WH at paragraph 29 had 
already laid down the requirement that 'a detailed list of surrogacy expenses with sufficient specificity should be provided') ${ }^{[2]}$ Furthermore, the court expressed concern about the surrogate mother's financial position: the intended surrogate mother lived with her life partner and his extended family on a smallholding; no facts were placed before the court regarding any of these people's income. However, the municipal account for the smallholding, which was attached to serve as proof of the surrogate mother's residence, revealed that about ZAR15 000 was outstanding. Based on these facts, the court decided that there was a risk that the intended surrogate mother was using surrogacy as a means of income.

The court's second reason for dismissing the application was concern about the intended surrogate mother's psychological wellbeing - in spite of the psychological report that declared the intended surrogate mother suitable to become a surrogate mother. The court highlighted the following facts from the commissioning mother's founding affidavit: the intended surrogate mother, ND, fell pregnant with her first child at the age of 16 , and subsequently dropped out of school. There were no facts before the court that ND has since made any attempt to finish school or to gain any type of vocational training. Given these facts, the court rejected the psychologist's conclusion that ND is suitable to be a surrogate mother, as being unsupported by the facts. Does ND have the maturity to appreciate that she will have to hand over the child to the commissioning parents after birth? The court was not convinced of this, and held that it was not satisfied that ND has the maturity to appreciate the implications of her life decisions.

The third reason for dismissing the application is especially relevant to healthcare professionals involved in surrogacy. In this case, the reproductive medicine specialist who provided the court with his opinion on the commissioning mother's infertility, and the psychologist who provided opinions on the applicants, both seem to be associated with the same fertility clinic. This fertility clinic would also have been contracted to provide in vitro fertilisation (IVF) treatment for the surrogate mother, had the application been successful. Given these facts, the court expressed two related concerns: firstly, about the objectivity of the relevant healthcare professionals, and secondly about the possible commercialisation of surrogacy. The court held that it had insufficient information about the exact financial arrangements between the relevant healthcare professionals and the clinic to make final findings on these concerns.

\section{Analysis}

The court in Ex Parte KAF held that, on the facts before it, it was unpersuaded about the suitability of the surrogate mother. However, the court did not elaborate on what information or kinds of information would have persuaded it otherwise. In other words, even if a clinical psychologist explores every aspect of a candidate surrogate mother's life in detail, and metaphorically looks under every stone, how does the psychologist decide whether a candidate is a suitable surrogate mother? Accordingly, the underlying problem in our law that was exposed in Ex Parte KAF is the lack of objective criteria for evaluating the suitability of a surrogate mother. I suggest that clinical psychologists who evaluate candidate surrogate mothers should give urgent and careful thought to identifying such objective criteria, and start explicitly articulating such criteria in the reports that they file in surrogate motherhood agreement confirmation applications. In fact, experts in general have a duty to furnish the court with the criteria that they used to reach their conclusions, so as to enable the court to form its own independent judgment by application of the criteria to the facts. ${ }^{[6]}$ Moreover, this practice would give the court the opportunity to engage with such criteria and to develop precedents in this regard. Absent clear, objective criteria, different psychologists and different judges will all be working with their own tacit, subjective criteria. This is clearly not in the interests of justice.

The Ex Parte KAF judgment emphasised the general legal requirement that experts must be objective in fact and in perception. But what exactly is meant by objectivity in our law? Can objectivity be reconciled with personal interests? The reality is that no expert - or even a judge - is ever completely free from personal interests. As the Constitutional Court held in paragraph 14 of its judgment in South African Commercial Catering and Allied Workers Union v Irvin \& Johnson (footnotes omitted): ${ }^{[7]}$

"Absolute neutrality" is something of a chimera in the judicial context. This is because judges are human. They are unavoidably the product of their own life experiences, and the perspective thus derived inevitably and distinctively informs each judge's performance of his or her judicial duties.'

The same is true of experts. The key to objectivity is not to have no personal interests - which is impossible - but rather to deliberately act free of such interests. The Missouri Court of Appeals succinctly articulated this principle, as it relates to expert opinions, as follows: ${ }^{[8]}$

"Objectivity" is the quality of being free from the influence of personal considerations in the exercise of professional skills and professional judgment.'

In the context of psychological reports on the suitability of surrogate mothers, the key to acting in an independent, objective way - and being perceived to act as such - is to implement the objective-criteria approach that I suggested above: a clinical psychologist should explicitly state the criteria used for evaluating the suitability of a surrogate mother, and should explain how these criteria are applied to the facts. In this way, a clinical psychologist will demonstrate that he or she does not merely provide a subjective opinion on suitability, but deliberately acts objectively.

\section{Conclusion}

Our legal system is dynamic and continuously developing - especially through case law. Ex Parte KAF applied some of the general principles of our law of evidence to surrogacy confirmation applications. The result is that a problematic lacuna in our law regarding surrogate motherhood has surfaced. To a large extent, applicants in surrogate motherhood agreement confirmation applications have been trying to jump through the suitable-surrogate-mother legal hoop in the dark. The way to illuminate this legal hoop is through the development of objective criteria.

Acknowledgements. None.

Author contributions. Sole author.

Funding. None.

Conflicts of interest. None. 
1. South Africa. Children's Act No. 38 of 2005. http://www.justice.gov.za/ legislation/acts/2005-038\%20childrensact.pdf (accessed 15 November 2017).

2. Ex Parte WH (2011) ZAGPPHC 185; 2011 (6) SA 514 (GNP). http://www.saflii.org/ za/cases/ZAGPPHC/2011/185.html (accessed 15 November 2017).

3. Ex Parte MS 2014ZAGPPHC 457. http://www.saflii.org/za/cases/ZAGPPHC/2014/457. html (accessed 15 November 2017)

4. Ex Parte HPP; Ex Parte DME 2017 ZAGPPHC 70; 2017 (4) SA 528 (GP). http://www. saflii.org/za/cases/ZAGPPHC/2017/70.html (accessed 15 November 2017).

5. Ex Parte KAF 2017 ZAGPJHC 227. http://www.saflii.org/za/cases/ZAGPJHC/2017/227. html (accessed 15 November 2017).

6. Twine v Naidoo 2017 ZAGPJHC 288. http://www1.saflii.org/za/cases/ ZAGPJHC/2017/288.html (accessed 15 November 2017).
7. South African Commercial Catering and Allied Workers Union v Irvin \& Johnson Limited Seafoods Division Fish Processing 2000 ZACC 10; 2000 (3) SA 705. http://www.saflii.org/za/cases/ZACC/2000/10.html (accessed 15 November 2017).

8. State Ex Rel. Lichtor v Clark, 845 S.W.2d 55 (Mo. Ct. App. 1992). https://www. courtlistener.com/opinion/2429713/state-ex-rel-lichtor-v-clark/ (accessed 15 November 2017).

Accepted 29 January 2018. 